ISSN: 2302-8556

E-Jurnal Akuntansi Universitas Udayana

Vol.25.2.November (2018): 1565-1590

DOI: https://doi.org/10.24843/EJA.2018.v25.i02.p28

\title{
Peran Turnover Intention Dalam Memediasi Pengaruh Locus Of Control Terhadap Perilaku Disfungsional Auditor
}

\section{Ni Wayan Utari Ningsih ${ }^{1}$ I Dewa Nyoman Badera ${ }^{2}$}

\author{
${ }^{1}$ Fakultas Ekonomi dan Bisnis Universitas Udayana (Unud), Bali, Indonesia \\ email: utari.ningsih@yahoo.com/ Telp: 082144642536 \\ ${ }^{2}$ Fakultas Ekonomi dan Bisnis Universitas Udayana (Unud), Bali, Indonesia
}

\begin{abstract}
ABSTRAK
Seorang Auditor melaksanakan profesinya harus mampu menghindari terjadinya perilaku disfungsional dengan memperhatikan faktor yang mempengaruhinya. Tujuan penelitian untuk mengetahui peran turnover intention dalam memediasi pengaruh locus of control terhadap perilaku disfungsional auditor di PT Bank Sinar Mas, jumlah auditor sebanyak 40 orang sebagai sampel melalui metode sample jenuh. Data dikumpulkan dengan menyebarkan kuesioner kepada 40 auditor yang memenuhi kriteria diolah melalui teknik analisis jalur . Berdasarkan hasil analisis, variabel locus of control berpengaruh positif dan signifikan terhadap perilaku disfungsional auditor di PT Bank Sinar Mas Denpasar. locus of control berpengaruh positif dan signifikan terhadap turnover intention di PT Bank Sinar Mas Denpasar. Turnover intention berpengaruh positif dan signifikan terhadap perilaku disfungsional auditor.
\end{abstract}

Kata kunci: locus of control, turnover intention, perilaku disfungsional audit

\section{ABSTRACT}

An auditor carrying out his profession must be able to avoid the occurrence of dysfunctional behavior by paying attention to the factors that influence it. The research objective is to determine the role of turnover intention in mediating the influence of locus of control on dysfunctional auditor behavior in PT Bank Sinar Mas with a total of 40 auditors as samples through saturated sample methods. Based on the results of the analysis, locus of control variables have a positive and significant effect on auditor dysfunctional behavior. Locus of control has a positive and significant effect on turnover intention. Turnover intention has a positive and significant effect on auditor dysfunctional behavior. Turnover intention mediates the positive influence of locus of control on auditor dysfunctional behavior.

Keywords: locus of control, turnover intention, dysfunctional audit behavior 


\section{PENDAHULUAN}

Bank mempunyai peranan sangat penting dalam menggerakkan roda perekonomian suatu negara, serta sebagai lembaga keuangan yang usaha pokoknya memberikan kredit kepada pihak yang memerlukan dana dan dalam lalu lintas pembayarannya adalah untuk mendapatkan pendapatan (Kasmir, 2008:62). Pendapatan bank ini penting untuk kelangsungan hidup suatu bank, disamping itu pendapatan ini juga dapat membesarkan usaha bank (Faisal, 2007).

Fenomena masalah yang sering terjadi di perbankan dalam penyaluran pinjaman yang dilakukan dapat terjadi timbulnya kredit macet atau kredit bermasalah. Masalah lainnya seperti kecurangan ( fraud) sering diartikan sebagai perbuatan curang yang dilakukan dengan berbagai cara licik dan bersifat menipu serta sering tidak disadari oleh korban yang dirugikan. Di bidang perbankan, dapat diartikan sebagai tindakan sengaja melanggar ketentuan internal (kebijakan, sistem dan prosedur) dan peraturan perundang-undangan yang berlaku demi kepentingan pribadi atau pihak lain yang berpotensi merugikan bank, baik material maupun moril. Dari kasus-kasus yang pernah terjadi di PT Bank Sinar Mas Denpasar tidak sedikit pekerja yang diberhentikan secara tidak hormat dikarenakan terlibat dalam kasus kecurangan ini seperti kredit fiktif, penggunaan uang, penyalahgunaan wewenang dll.

PT Bank Sinar Mas Denpasar dalam mengatasi terjadinya kecurangan (fraud) dibentuk audit internal sebagai biro pengawasan untuk mencegah kecurangan dalam suatu perusahaan yang kegiatannya meliputi menguji dan menilai efektivitas serta kecukupan sistem pengendalian internal yang ada dalam perusahaan. Tindakan- 
ISSN: 2302-8556

E-Jurnal Akuntansi Universitas Udayana

Vol.25.2.November (2018): 1565-1590

tindakan pengawasan tersebut adalah cara untuk mengatasi kecurangan sehingga kehilangan keuangan negara dapat terus ditekan dan pada akhirnya tercapai tujuan untuk menghilangkan kebocoran dan kerugian negara (Gaffikin \& Lindawati, 2012). Melalui pengawasan intern dapat diketahui apakah suatu instansi/ perusahaan telah melaksanakan kegiatan sesuai dengan tugas dan fungsinya secara efektif dan efisien, serta sesuai dengan rencana, kebijakan yang telah ditetapkan. Selain itu, pengawasan intern diperlukan untuk mendorong terwujudnya good governance dan clean government dan mendukung pengawasan perusahaan yang efektif, efisien, transparan, akuntabel serta bersih dan bebas dari praktik korupsi, kolusi dan nepotisme (Balkish et al., 2013).

Pemeriksaan internal atau internal auditing merupakan tugas dari auditor internal. Peran auditor internal sangatlah penting dalam memberikan kontribusi kepada pihak manajemen dimana aktivitas audit tidak lagi terfokus kepada keuangan perusahaan, namun juga telah banyak terlibat ke dalam bidang operasional antara lain seperti produksi, penjualan, distribusi personil, dan lain sebagainya di samping untuk peningkatan efisiensi dan efektifitas kegiatan perusahaan (Kasmir, 2008:2-3). Auditor internal dituntut untuk melakukan pekerjaannya secara profesional, yakni dengan menjunjung tinggi standar mutu pekerjaan dan menaati kode etik profesi. Karena sebagai suatu profesi, para internal auditor di lingkungan perbankan memiliki suatu peran atau role yang didefinisikan sebagai suatu pola fungsi dan tugas yang diharapkan oleh lingkungannya untuk dikerjakan oleh individu tersebut (Alvin et al., 
2008:3). Seorang auditor internal dalam melaksanakan tugasnya melalui pola fungsi dan tugasnya diharapkan menghindari terjadinya perilaku disfungsional auditor (Rustiarini, 2014).

Perilaku disfungsional auditor dalam pelaksanaan program audit merupakan faktor penting yang berpengaruh terhadap hasil temuan audit (Ade, 2008). Perilaku audit disfungsional adalah setiap tindakan yang dilakukan auditor dalam pelaksanaan audit yang dapat mereduksi atau menurunkan hasil temuan audit secara langsung maupun tidak langsung (Kelley dan Margheim, 1990; dalam Ade, 2008). Sartika (2013) menyatakan terjadinya perilaku disfungsional auditor terhadap kewajaran sebuah laporan keuangan, disebabkan oleh banyak faktor, salah satunya adalah locus of control.

Peran internal auditor di lingkungan perbankan sebagai pelaksana dari biro pengawasan dalam melakukan tugasnya tentunya juga tidak terlepas dari terjadinya konflik-konflik kepentingan, baik itu antar individu, antar departemen maupun antar individu dan perusahaan. Ceacilia et al. (2016) mengemukakan bahwa penyebab para auditor melakukan perilaku disfungsional tersebut adalah karakteristik personal yang berupa lokus kendali terdiri dari lokus kendali internal (internal locus of control) maupun lokus kendali eksternal (external locus of control), keinginan untuk berhenti bekerja (turnover intention) yang dimiliki oleh para auditor. Robbins (2008: 138) menyatakan bahwa locus of control adalah seberapa besar keyakinan seseorang pada diri mereka sendiri dalam menentukan nasib mereka sendiri. Locus of control 
ISSN: 2302-8556

E-Jurnal Akuntansi Universitas Udayana

Vol.25.2.November (2018): 1565-1590

seseorang dibedakan atas kecenderungan sudut pandang seseorang yaitu locus of control eksternal dan locus of control internal. Robbins (2008: 138) menyatakan jika individu memiliki locus of control internal berarti individu tersebut lebih meyakini bahwa diri mereka mereka sebagai penentu nasib mereka. Ceacilia et al. (2016) menjelaskan individu yang lebih meyakini bahwa sesuatu yang terjadi pada diri mereka karena disebabkan oleh kekuatan di luar dirinya menandakan individu tersebut memiliki locus of control eksternal (David et al., 2013).

Paneeda \& Phaprukbaramee (2015) menyatakan perilaku disfungsional auditor sebagai perilaku yang menyimpang dari seorang auditor tentu saja dipengaruhi oleh beberapa faktor diluar locus of control, antara lain adalah turnover intention. Syarhayuti \& Faidul (2016) menyatakan salah satu permasalahan serius yang dapat mempengaruhi perilaku disfungsional auditor adalah perilaku turnover karyawan. Hanifah (2017) turnover yang tinggi berbahaya bagi perusahaan dan hal tersebut juga mengurangi efisiensi dan produktivitas organisasi. Alan \& Todd (2011) serta Gaffikin, \& Lindawati (2012) menyatakan efek negatif tingginya tingkat turnover juga dapat menimbulkan pemborosan biaya yang cukup besar karena perusahaan harus menginvestasikan biaya untuk melakukan rekrutmen, orientasi, pelatihan, lembur, dan pengawasan dalam pembentukan tim audit internal.

Mark (2009) menyatakan begitu pentingnya hasil temuan audit yang diberikan oleh auditor bagi sebuah perusahaan, maka seorang auditor dituntut untuk menghindari terjadinya perilaku disfungsional. Seorang auditor harus menekan sikap 
turnover intention dan mampu mengendalikan locus of control baik internal maupun external sehingga auditor dapat menggunakan kemahiran profesionalnya dengan cermat dan seksama, apabila sikap turnover intention meningkat tentu akan memicu terjadinya pengendalian locus of control yang rendah sehingga akan menimbulkan perilaku disfungsional auditor dalam bekerja (Peyman \& Ali, 2016).

Melalui pemaparan masalah yang telah dijabarkan, maka dapat dirumuskan masalah penelitian yaitu (1) Bagaimakah pengaruh locus of control terhadap perilaku disfungsional auditor di PT Bank Sinar Mas Denpasar, (2) Bagaimakah pengaruh locus of control terhadap turnover intention di PT Bank Sinar Mas Denpasar, (3) Bagaimakah pengaruh turnover intention terhadap perilaku disfungsional auditor di PT Bank Sinar Mas Denpasar, (4) Apakah turnover intention memediasi pengaruh locus of control terhadap perilaku disfungsional auditor di PT Bank Sinar Mas Denpasar.

Alkautsar (2014) mengatakan bahwa sikap (attitudes) merupakan suatu penilaian yang melibatkan penalaran logis sadar atas gambaran suatu keyakinan, penilaian atas perasaan, dan suatu intensi (niatan) perilaku terhadap seseorang, obyek, atau peristiwa yang disebut dengan attitude object. Menurut Cacioppo et al (1994) dalam Siti (2013), perubahan sikap (attitude change) mengacu pada modifikasi umum persepsi evaluatif individu atas stimulus atau serangkaian rangsangan. 
ISSN: 2302-8556

E-Jurnal Akuntansi Universitas Udayana

Vol.25.2.November (2018): 1565-1590

Menurut Mulyadi (2011) auditor dapat dibedakan menjadi tiga jenis, antara lain: auditor pemerintah adalah auditor yang bertugas melakukan audit atas keuangan Negara pada instansi-instansi pemerintah. Di Indonesia audit ini dilakukan oleh Badan Pemeriksaan Keuangan (BPK). Eksternal auditor atau akuntan public adalah seorang praktisi dan gelar professional yang diberikan kepada akuntan di Indonesia yang telah mendapat izin untuk memberikan jasa audit umum dan review atas laporan keuangan, audit kinerja, dan audit khusus serta jasa nonassurancce seperti jasa konsultasi, jasa kompilasi, jasa perpajakan. Jasa-jasa yang ditawarkan oleh akuntan publik ini dilakukan pada perusahaan terbuka, yaitu perusahaan yang go public, perusahaan-perusahaan besar dan juga perusahaan kecil serta organisasi yang tidak bertujuan mencari laba. Praktik akuntan publik harus dilakukan melalui suatu Kantor Akuntan Publik (KAP). Internal auditor merupakan auditor yang bekerja suatu perusahaan dan oleh karenanya berstatus sebagai pegawai pada perusahaan tersebut. Tugas utamanya ditujukan untuk membantu manajemen perusahaan tempat dimana ia bekerja.

Audit Internal mempunyai peranan yang sangat penting dalam mencapai tujuan perusahaan yang telah ditentukan. Perlunya konsep audit internal dikarenakan bertambah luasnya ruang lingkup perusahaan. Audit internal yang memberikan nilai, mengatur badan dan manajemen senior sebagai sumber tujuan saran independen. Profesional yang disebut auditor internal yang digunakan oleh organisasi untuk melakukan kegiatan audit internal. Saat ini profesi audit internal terus mengalami 
perkembangan sesuai dengan tuntutan berkembangnya dunia usaha dan perekonomian yang menuntut suatu perusahaan untuk menjalankan kegiatannya secara profesional, yang berarti pemanfaatan sumber daya secara efektif dan efisien sesuai dengan tujuan perusahaan.

Dysfunctional audit behavior (DAB) merupakan suatu bentuk reaksi terhadap lingkungan yang berkaitan dengan sistem pengendalian (Donnelly et al., 2013). Sistem pengendalian yang berlebih dalam suatu organisasi dapat mengakibatkan timbulnya konflik yang mengarah pada perilaku disfungsional. Donnelly et al. (2013) dalam (Mahatma dan Suaryana, 2016) menjelaskan apabila auditor bersikap menerima perilaku disfungsional, hal tersebut mengindikasikan bahwa auditor tersebut telah melakukan disfungsional aktual. Perilaku disfungsional audit dapat memberikan pengaruh pada kualitas audit, baik secara langsung maupun tidak langsung. Perilaku yang mempunyai pengaruh langsung diantaranya adalah premature sign off dan altering atau replacing audit procedures (Hanifah, 2017).

\section{Locus of Control}

Kreitner dan Kinicki (2008:351) mendefinisikan salah satu karakteristik personal yang membedakan individu yang satu dengan individu yang lain adalah pusat kendali yang biasa disebut locus of control. Locus of control adalah konsep yang dikembangkan oleh Julian B. Rotter dimana diungkapkan bahwa setiap individu membangun ekspektasi tentang kesuksesan mereka yang bergantung atas tingkah laku atau pada hal yang di luar diri mereka (Mangkunegara, 2011:28). 
ISSN: 2302-8556

E-Jurnal Akuntansi Universitas Udayana

Vol.25.2.November (2018): 1565-1590

Turnover Intention dapat diartikan sebagai pergerakan tenaga kerja keluar dari organisasi. Turnover menurut Robbins dan Judge (2011:38) adalah tindakan pengunduran diri secara permanen yang dilakukan oleh karyawan baik secara sukarela ataupun tidak secara sukarela. Turnover dapat berupa pengunduran diri, perpindahan keluar unit organisasi, pemberhentian atau kematian anggota organisasi. Faisal (2007) menyebutkan turnover intention merupakan prediktor terbaik untuk mengindentifikasi perilaku turnover yang akan terjadi pada karyawan suatu organisasi.

Robbins dan Judge (2011: 181-182) menyatakan indikator-indikator yang mempengaruhi terjadinya turnover cukup kompleks dan saling berkaitan satu sama lain. Diantara indikator-indikator tersebut yang akan dibahas antara lain sebagai berikut: Usia, dimana tingkat turnover yang cenderung lebih tinggi pada karyawan berusia muda disebabkan karena mereka memiliki keinginan untuk mencoba-coba pekerjaan atau organisasi kerja serta ingin mendapatkan keyakinan diri lebih besar melalui cara coba-coba tersebut (Hanifah, 2017). Lama Kerja dimana semakin lama masa kerja semakin rendah kecenderungan turnovernya. Turnover terjadi karena rendahnya pelaksanaan talent management dengan kurangnya sosialisasi yang dilaksanakan perusahaan terhadap karyawan. Tingkat pendidikan dan intellegensi tidak terlalu tinggi akan memandang tugas-tugas yang sulit sebagai tekanan dan sumber kecemasan yang disebut dengan out-group. Keterikatan terhadap perusahaan yang mempunyai rasa keterikatan yang kuat terhadap perusahaan tempat ia bekerja 
berarti mempunyai dan membentuk perasaan memiliki (sense of belonging), rasa aman, efikasi, tujuan dan arti hidup serta gambaran diri positif. Akibat secara langsung adalah menurunnya dorongan diri untuk berpindah pekerjaan dan perusahaan (Sudarshan, 2015).

Attitude change theory menjelaskan bahwa penyebab para auditor melakukan perilaku disfungsional tersebut adalah karakteristik personal yang berupa lokus kendali terdiri dari lokus kendali internal (internal locus of control) maupun lokus kendali eksternal (external locus of control). Ceacilia et al. (2016) menyatakan locus of control berpengaruh positif terhadap perilaku disfungsional auditor. Siti (2017) menyatakan locus of control berpengaruh positif terhadap perilaku disfungsional auditor. Sartika (2013) menyatakan locus of control berpengaruh positif terjadinya tindakan perilaku disfungsional auditor. David et al. (2013) menyatakan locus of control berpengaruh positif terhadap perilaku disfungsional auditor. Dari penjelasan di atas, maka hipotesis yang dapat dirumuskan adalah sebagai berikut: $\mathrm{H}_{1}$ : locus of control berpengaruh positif terhadap perilaku disfungsional auditor Ceacilia et al. (2016) mengemukakan melalui attitude change theory bahwa perilaku turnover dapat diukur melalui intensi atau niatan terhadap perilaku internal control dan external control. Sartika (2013) menyatakan locus of control memiliki pengaruh positif pada turnover intention. Syarhayuti \& Faidul (2016) menyatakan locus of control memiliki pengaruh positif terhadap turnover intention. Ceacilia et al. (2016) menyatakan locus of control berpengaruh terhadap turnover intention. Siti 
ISSN: 2302-8556

E-Jurnal Akuntansi Universitas Udayana

Vol.25.2.November (2018): 1565-1590

(2017) menyatakan locus of control berpengaruh positif pada turnover intention. Berdasarkan uraian tersebut maka hipotesis yang diajukan adalah sebagai berikut:

$\mathrm{H}_{2}$ : locus of control berpengaruh positif terhadap turnover intention.

Attitude change theory menjelaskan perilaku disfungsional audit adalah perilaku auditor dalam proses audit yang tidak sesuai dengan program audit yang menyimpang dari standar yang telah ditetapkan (Medhat \& Gary, 2015). Ceacilia et al. (2016) menyatakan turnover intention berpengaruh terhadap perilaku disfungsional auditor. Siti (2017) menyatakan turnover intention berpengaruh positif pada perilaku disfungsional auditor. Sartika (2013) menyatakan turnover intention memiliki pengaruh positif pada perilaku disfungsional auditor. Syarhayuti \& Faidul (2016) menyatakan turnover intention memiliki pengaruh positif terhadap perilaku disfungsional auditor. Berdasarkan uraian diatas, maka hipotesis yang dapat dirumuskan hasil penelitian sebagai berikut:

$\mathrm{H}_{3}$ : turnover intention berpengaruh positif terhadap perilaku disfungsional auditor

Mark (2009) menyatakan begitu pentingnya hasil temuan audit yang diberikan oleh auditor bagi sebuah perusahaan, maka seorang auditor dituntut untuk menghindari terjadinya perilaku disfungsional. Ceacilia et al. (2016) menyatakan turnover intention mampu memediasi pengaruh locus of control terhadap perilaku disfungsional auditor. Siti (2017) menyatakan turnover intention mampu memediasi pengaruh locus of control sehingga terjadinya tindakan perilaku disfungsional auditor. Sartika (2013) menyatakan turnover intention mampu memediasi pengaruh 
locus of control sehingga terjadinya tindakan perilaku disfungsional auditor. Syarhayuti \& Faidul (2016) menyatakan turnover intention mampu memediasi pengaruh locus of control terhadap perilaku disfungsional auditor. Dari penjelasan di atas, maka hipotesis yang dapat dirumuskan adalah sebagai berikut.

$\mathrm{H}_{4}$ : turnover intention memediasi pengaruh positif locus of control terhadap perilaku disfungsional auditor.

Model Konseptual

Berdasarkan penelusuran moderasi analisis dan hasil-hasil penelitian terdahulu maka model penelitian dapat digambarkan seperti berikut :

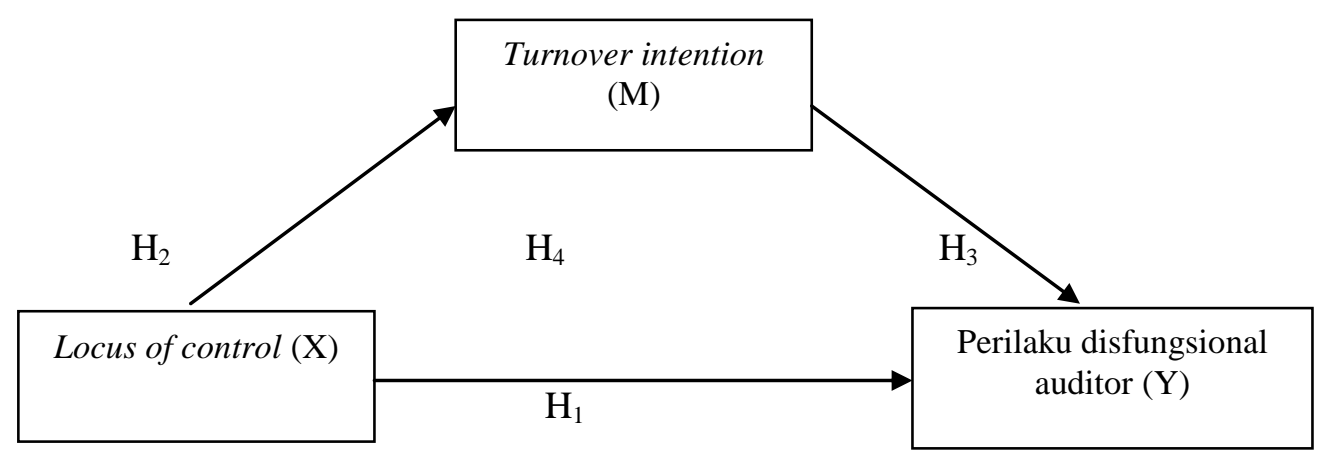

Gambar 1. Model kerangka berfikir

Sumber: Data diolah, 2017

\section{METODE PENELITIAN}

Karya ilmiah ini dilakukan dengan tujuan untuk mengetahui hubungan antara satu sampai dua variabel atau lebih. Melalui studi asosiatif dapat dibangun suatu teori yang berfungsi untuk menjelaskan, meramalkan dan mengontrol suatu gejala/fenomena hubungan antara variabel-variabel. 
ISSN: 2302-8556

E-Jurnal Akuntansi Universitas Udayana

Vol.25.2.November (2018): 1565-1590

Penelitian ini memfokuskan lokasi studi pada seluruh kantor cabang PT Bank Sinar Mas Denpasar yang terdapat pada wilayah Provinsi Bali meliputi Denpasar, Badung, Tabanan, Gianyar dan Singaraja tahun 2018 dengan jumlah kantor sebanyak delapan kantor.

Sumber data untuk mendukung makalah studi ini seperti sumber data primer dan sekunder. Data primer melalui data yang dikumpulkan dari dengan observasi dan pemberian kuesioner kepada responden yaitu auditor yang bekerja di Bank Sinar Mas Denpasar. Data sekunder sebagai pendukung adalah teori-teori pendukung, artikelartikel, serta data survey mengenai kinerja auditor di Bank Sinar Mas Denpasar.

Populasi dan Sampel

Populasi dalam penelitian ini adalah seluruh auditor yang bekerja di Bank Sinar Mas Denpasar. yang berjumlah 40 orang dengan menggunakan metode sensus (Riduwan dan Sunarto, 2007:17) sebagai berikut.

Tinggi rendahnya validitas instrumen menunjukkan sejauh mana data yang terkumpul tidak menyimpang dari gambaran tentang variabel yang dimaksud. Menurut Santoso (2013:135) syarat minimum untuk dianggap memenuhi syarat adalah kalau $\mathrm{r}=0,3$ ”. Jadi kalau korelasi antara butir skor dengan skor total kurang dari 0,3 maka butir dalam instrumen tersebut dinyatakan tidak valid.

Uji reliabilitas bertujuan untuk mencari nilai suatu instrumen dikatakan realiabel bila nilai Alpha Cronbach $\geq 0,6$. Dalam penelitian ini, untuk menguji reliabilitas dengan teknik analisis dengan formula alpha cronbach. 
Uji Asumsi Klasik dibutuhkan sebaga syarat sebelum analisis utama dilakukan. Uji tersebut terdiri atas (1) Uji Normalitas, bertujuan untuk menguji apakah suatu data berdistribusi normal atau tidak dengan model regresi memenuhi asumsi normalitas atau tidak (2) Uji Multikolonieritas, uji ini sebagai pedoman untuk mengetahui satu model yang bebas multikol adalah mempunyai nilai Varian Inflatation Factor (VIF) tidak lebih dari 10 dan mempunyai angka tolerance tidak kurang dari 0,1. (3) Uji heteroskedastisitas dalam perhitungan SPSS untuk mendeteksi adanya heteroskedastisitas yaitu dengan cara melihat ada tidaknya pola tertentu pada grafik heteroskedastisitas dimana sumbu X dan Y yang telah diprediksi dan sumbu Y adalah residual (Y prediksi-Ysesungguhnya) yang telah distandardized.

Analisis Jalur (Path Analysis)

Teknik analisis data yang digunakan dalam penelitian ini adalah teknik analisis jalur (path analysis). Analisis jalur merupakan perluasan dari analisis regresi linier berganda, untuk menaksir hubungan kausalitas antar variabel yang berjenjang berdasarkan teori (Ghozali, 2012:135).

Pengaruh langsung variabel locus of control (X), berpengaruh terhadap turnover intention (M). Variabel locus of control (X), berpengaruh terhadap disfungsional auditor (Y). Variabel turnover intention (M), berpengaruh terhadap disfungsional auditor (Y). Pengujian hipotesis mediasi pengaruh tidak langsung variabel pengetahuan locus control $(\mathrm{X})$ terhadap variabel disfungsional auditor $(\mathrm{Y})$ melalui variabel turnover intention (M). 
ISSN: 2302-8556

E-Jurnal Akuntansi Universitas Udayana

Vol.25.2.November (2018): 1565-1590

\section{HASIL DAN PEMBAHASAN}

Uji Validitas menjelaskan sebuah instrumen dikatakan valid jika memenuhi syarat $\mathrm{r}=$ 0,3". Hasil uji validitas membukitan hasil masih-masing indikator variabel memiliki nilai person correlation lebih besar dari 0,30 . Uji reliabilitas mampu menunjukan sejauh mana instrument dapat dipercaya dengan nilai suatu instrumen dikatakan reliabel bila nilai Alpha Cronbach $\geq 0,6$.

Uji normalitas akan ditampilkan pada gambar menggunakan uji KolmogorovSmirnov dengan signifikansi lebih besar dari 0,05 yaitu 0,556 maka dapat disimpulkan bahwa model regresi terdistribusi secara normal. Uji Multikolinearitas dengan nilai tolerance masing-masing variabel lebih besar dari 0,1 dan nilai VIF lebih kecil dari 10, sehingga dapat disimpulkan bahwa dalam model regresi tidak terjadi multikolinearitas dan dapat digunakan dalam penelitian ini. Uji heteroskedastisitas bertujuan untuk menguji apakah model regresi terjadi ketidaksamaan varians dari residual pengamatan ke pengamatan yang lain. Hasil membuktikan nilai signifikansi masing-masing variabel lebih besar dari 0,05 yang berarti variabel tersebut bebas heteroskedastisitas.

\section{Tabel 1.}

Rekapitulasi Hasil Struktur 1

\begin{tabular}{llccc}
\hline \multicolumn{1}{c}{ Model } & $\begin{array}{c}\text { Standardized } \\
\text { Coefficients } \\
\text { Beta }\end{array}$ & T & Sig. \\
\hline (Constant) & 4.449 & 3.246 & 0.002 \\
locus of control & 0.578 & 8.148 & 0.000 \\
$\mathrm{R}^{2}$ & & & \\
F Statistik $\quad: 0,636$ & $: 66,386$ & & \\
Sig.F & $: 0,000$ & & & \\
\hline Sumber: data diolah, 2018 & &
\end{tabular}


Berdasarkan laporan pada Tabel 1, maka persamaan strukturalnya adalah sebagai berikut:

$$
\mathrm{M}=0.578 \mathrm{X}
$$

Tabel 1 menjelaskan hasil pengujian pengaruh variabel locus of control (X) terhadap turnover intention (M) dijelaskan bahwa locus of control berpengaruh positif signifikan terhadap turnover intention dengan nilai standardized coefficients beta sebesar 0,578 dan nilai sig t sebesar $0,000<0,05$.

Pengaruh variabel locus of control (X), turnover intention (M) terhadap perilaku disfungsional audit (Y)

Tabel 2.

Rekapitulasi Hasil Struktur 2

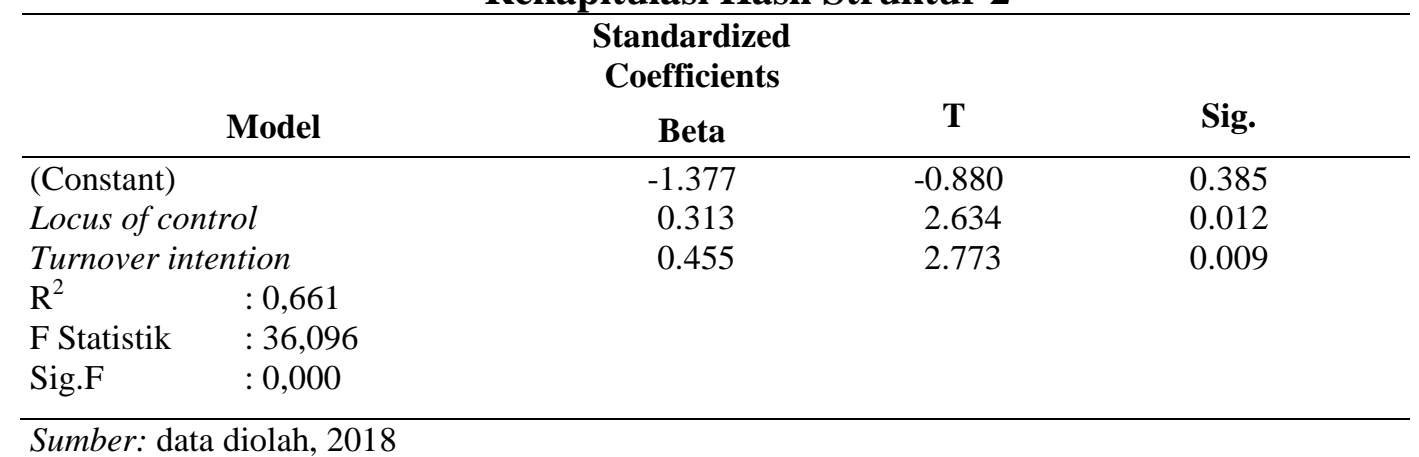

Berdasarkan laporan pada Tabel 2, maka persamaan strukturalnya adalah sebagai berikut:

$$
\mathrm{Y}=0.313 \mathrm{X}+0,455 \mathrm{M}
$$

Tabel 2 menjelaskan hasil pengujian pengaruh variabel locus of control (X) dan turnover intention (M) terhadap perilaku disfungsional audit (Y) dijelaskan bahwa locus of control berpengaruh positif signifikan terhadap perilaku disfungsional 
ISSN: 2302-8556

audit dengan nilai standardized coefficients beta sebesar 0,313 dan nilai sig t sebesar $0,012<0,05$.

Turnover intention berpengaruh positif signifikan terhadap perilaku disfungsional audit dengan nilai standardized coefficients beta sebesar 0,455 dan nilai sig t sebesar $0,009<0,05$.

Pengujian pengaruh variabel locus of control (X) terhadap perilaku disfungsional audit $(\mathrm{Y})$ dengan mediasi turnover intention $(\mathrm{M})$ digambarkan dengan model diagram jalur seperti pada Gambar 4.2 berikut.

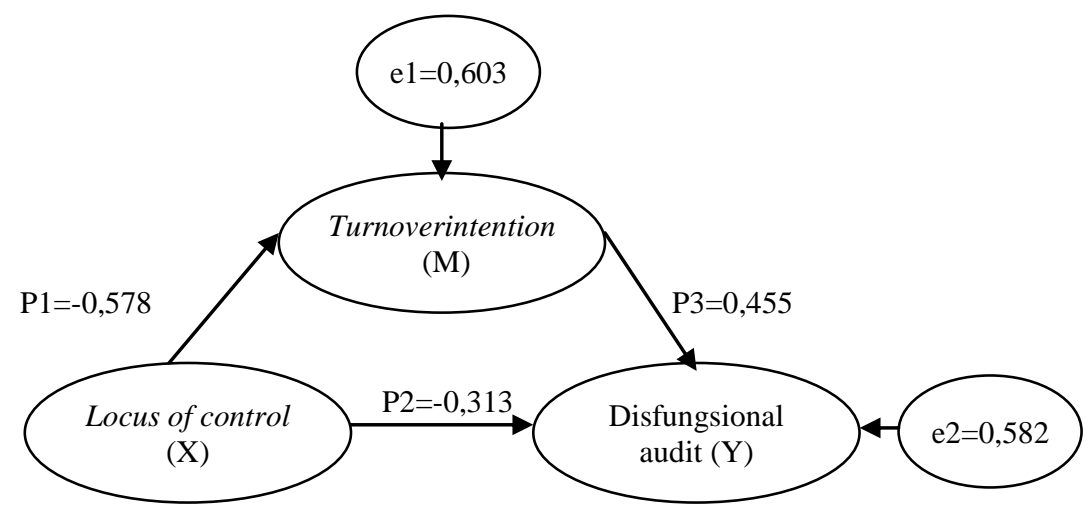

Gambar 2. Model Diagram Jalur Akhir

Gambar 2 menunjukkan nilai koefisien jalur pada model pengaruh locus of control terhadap perilaku disfungsional audit dengan mediasi turnover intention. Gambar 2 diketahui bahwa koefisien jalur pengaruh locus of control terhadap variabel perilaku disfungsional audit setelah variabel turnover intention dimasukan ke dalam model bernilai 0,455 tidak bernilai 0, yang berarti turnover intention memediasi pengaruh positif locus of control terhadap perilaku disfungsional audit pada PT Bank Sinar Mas di Denpasar. 
Hasil perhitungan didapatkan perbandingan nilai $\mathrm{z}$ hitung sebesar 6,38 > z tabel sebesar 1,96, maka Ho ditolak dan Hi diterima. Artinya turnover intention memediasi pengaruh locus of control terhadap perilaku disfungsional audit pada PT Bank Sinar Mas Denpasar. Nilai determinasi total sebesar 0,888 mempunyai arti bahwa sebesar $88,8 \%$ variasi perilaku disfungsional audit dipengaruhi oleh variabel turnover intention dan locus of control, sedangkan sisanya sebesar 11,2 persen dijelaskan oleh faktor lain yang tidak dimasukkan ke dalam model.

Berdasarkan hasil dari koefisien jalur pada hipotesis penelitian, perhitungan pengaruh antar variabel dirangkum dalam Tabel 3.

\section{Tabel 3.}

Pengaruh langsung, pengaruh tidak langsung serta pengaruh total locus of control $(\mathrm{X})$ terhadap perilaku disfungsional audit $(\mathrm{Y})$ dengan mediasi turnover intention (M)

\begin{tabular}{llccc}
\hline Pengaruh Variabel & $\begin{array}{c}\text { Pengaruh } \\
\text { Langsung }\end{array}$ & $\begin{array}{c}\text { Pengaruh Tidak } \\
\text { Langsung M } \\
(\mathbf{p 1} \text { x p3) }\end{array}$ & Pengaruh Total \\
\hline P1 & $\mathrm{X} \rightarrow \mathrm{Y}$ & 0,313 & - & 0,313 \\
P2 & $\mathrm{X} \rightarrow \mathrm{M}$ & 0,578 & - & 0,578 \\
P3 & $\mathrm{M} \rightarrow \mathrm{Y}$ & 0,455 & - & 0,455 \\
$\mathrm{P} 4$ & $\mathrm{X} \rightarrow \mathrm{M} \rightarrow \mathrm{Y}$ & 0,578 & 0,142 & 0,720 \\
\hline
\end{tabular}

Sumber: data diolah, 2018

Hasil uji parsial menunjukan bahwa Locus of control (X) terbukti berpengaruh positif dan signifikan terhadap perilaku disfungsional audit (Y), yang ditunjukkan oleh nilai koefisien jalur sebesar 0,313 , dengan tingkat signifikansi atau $p$ value $=$ 0,012, yang berarti sangat signifikan.

Hasil uji parsial menunjukan bahwa locus of control (X) terbukti berpengaruh positif dan signifikan terhadap turnover intention (M), yang ditunjukkan oleh nilai 
ISSN: 2302-8556

E-Jurnal Akuntansi Universitas Udayana

Vol.25.2.November (2018): 1565-1590

koefisien jalur sebesar 0,578 , dengan tingkat signifikansi atau $p$ value $=0,000$, yang berarti sangat signifikan.

Hasil uji parsial menunjukan bahwa turnover intention (M) terbukti berpengaruh positif terhadap kinerja auditor (Y), yang ditunjukkan oleh nilai koefisien jalur sebesar 0,455 , dengan tingkat signifikansi atau $p$ value $=0,009$, yang berarti sangat signifikan.

Hasil uji parsial menunjukan bahwa turnover intention (M) memediasi pengaruh positif locus of control (X) terhadap perilaku disfungsional audit (Y), yang ditunjukkan oleh nilai koefisien jalur sebesar 0,7200, dengan tingkat signifikansi atau $p$ value $=0,000$, yang berarti sangat signifikan

Hasil menunjukan bahwa locus of control berpengaruh positif dan signifikan terhadap perilaku disfungsional audit pada PT Bank Sinar Mas Denpasar. Terjadinya locus of control yang dialami oleh seorang auditor secara langsung akan menyebabkan terjadi perilaku disfungsional auditor. Attitude change theory menjelaskan bahwa penyebab para auditor melakukan perilaku disfungsional tersebut adalah karakteristik personal yang berupa lokus kendali terdiri dari lokus kendali internal (internal locus of control) maupun lokus kendali eksternal (external locus of control).

Hasil penelitian ini sama dengan penelitian Ceacilia et al. (2016) menyatakan locus of control berpengaruh positif terhadap perilaku disfungsional auditor. Siti (2017) menyatakan locus of control berpengaruh positif terhadap perilaku 
disfungsional auditor. Sartika (2013) menyatakan locus of control berpengaruh positif terjadinya tindakan perilaku disfungsional auditor. David et al. (2013) menyatakan locus of control berpengaruh positif terhadap perilaku disfungsional auditor.

Pengaruh locus of control terhadap turnover intention

Hasil menunjukan bahwa locus of control berpengaruh positif dan signifikan terhadap turnover intention auditor pada PT Bank Sinar Mas Denpasar. Attitude change theory menjelaskan perilaku turnover dapat diukur melalui intensi atau niatan terhadap perilaku internal control dan external control. Turnover intention terbentuk dipicu oleh beberapa variabel sikap yang menurut traditional turnover theory yaitu adalah sikap tekanan kerja, locus of control serta menimbulkan perilaku disfungsional audit (Suriana, 2014).

Hasil penelitian ini sesuai dengan penelitian Sartika (2013) menyatakan locus of control memiliki pengaruh positif pada turnover intention. Syarhayuti \& Faidul (2016) menyatakan locus of control memiliki pengaruh positif terhadap turnover intention. Ceacilia et al. (2016) menyatakan locus of control berpengaruh terhadap turnover intention. Siti (2017) menyatakan locus of control berpengaruh positif pada turnover intention.

Hasil menunjukan bahwa turnover intention berpengaruh positif terhadap perilaku disfungsional audit pada PT Bank Sinar Mas Denpasar. Attitude change theory menjelaskan perilaku disfungsional audit adalah perilaku auditor dalam proses audit yang tidak sesuai dengan program audit yang menyimpang dari standar yang 
ISSN: 2302-8556

E-Jurnal Akuntansi Universitas Udayana

Vol.25.2.November (2018): 1565-1590

telah ditetapkan (Medhat \& Gary, 2015). Turnover intention berimplikasi menyebabkan terjadinya perilaku disfungsional audit yang akan cenderung menghasilkan audit yang kurang berkualitas dan dapat menyesatkan para pengguna laporan tersebut (Ceacilia et al., 2016).

Hasil penelitian ini sesuai dengan penelitian Ceacilia et al. (2016) menyatakan turnover intention berpengaruh terhadap perilaku disfungsional auditor. Siti (2017) menyatakan turnover intention berpengaruh positif pada perilaku disfungsional auditor. Sartika (2013) menyatakan turnover intention memiliki pengaruh positif pada perilaku disfungsional auditor. Syarhayuti \& Faidul (2016) menyatakan turnover intention memiliki pengaruh positif terhadap perilaku disfungsional auditor.

Hasil menunjukan bahwa turnover intention mampu memediasi pengaruh positif locus of control terhadap perilaku disfungsional audit pada PT Bank Sinar Mas Denpasar. Seorang auditor harus menekan sikap turnover intention dan mampu mengendalikan locus of control baik internal maupun external sehingga auditor dapat menggunakan kemahiran profesionalnya dengan cermat dan seksama, apabila sikap turnover intention meningkat tentu akan memicu terjadinya pengendalian locus of control yang rendah sehingga akan menimbulkan perilaku disfungsional auditor dalam bekerja (Peyman \& Ali, 2016).

Hasil penelitian ini sesuai dengan penelitian Ceacilia et al. (2016) menyatakan turnover intention mampu memediasi pengaruh locus of control terhadap perilaku disfungsional auditor. Siti (2017) menyatakan turnover intention mampu memediasi 
pengaruh locus of control sehingga terjadinya tindakan perilaku disfungsional auditor. Sartika (2013) menyatakan turnover intention mampu memediasi pengaruh locus of control sehingga terjadinya tindakan perilaku disfungsional auditor. Syarhayuti \& Faidul (2016) menyatakan turnover intention mampu memediasi pengaruh locus of control terhadap perilaku disfungsional auditor.

\section{SIMPULAN}

Melihat dan memahami pembahasan pada bab-bab sebelumnya, maka hal-hal yang dapat disimpulkan adalah locus of control berpengaruh positif dan signifikan pada perilaku disfungsional audit di PT Bank Sinar Mas Denpasar. Locus of control berpengaruh positif dan signifikan pada turnover intention audit di PT Bank Sinar Mas Denpasar. Turnover intention berpengaruh positif dan signifikan pada perilaku disfungsional audit di PT Bank Sinar Mas Denpasar. Turnover intention memediasi pengaruh locus of control perilaku disfungsional audit di PT Bank Sinar Mas Denpasar.

Berdasarkan kesimpulan di atas, maka adapun saran yang dapat diberikan diharapkan bagi Bagi PT Bank Sinar Mas yang memiliki jasa audit, harus menjaga keterbukaan dengan memperhatikan ketepatan dalam pelaporan, meningkatkan pelaksanaan aktivitas penilaian pemeriksaan atas kebenaran data dan informasi dari sistem serta pengambilan kebijakan yang tepat, sehingga pengawasan dari auditor dalam pengumpulan bukti untuk mendukung temuan audit dapat menghindari perilaku disfungsional untuk mempertahankan keberlangsungan hidup perusahaan. 
ISSN: 2302-8556

E-Jurnal Akuntansi Universitas Udayana

Vol.25.2.November (2018): 1565-1590

Hasil penelitian ini diharapkan dapat memberikan kontribusi praktis bagi para praktisi auditor khususnya di PT Bank Sinar Mas agar dapat mempertimbangkan karakteristik yang menyebabkan perilaku disfungsional audit. Hal yang perlu diperhatikan antara lain seorang auditor harus memiliki sikap etis untuk menghindari locus of control didalam melaksanakan pemeriksaan audit. Sikap etis yang dimaksud adalah cekatan, jujur, murah hati dan terbuka di dalam memberikan hasil temuan kepada manajamen sehingga bermanfaat bagi kepentingan orang banyak.

Persamaan hubungan locus of control, turnover intention dan perilaku disfungsional audit dengan besaran nilai $\mathrm{R}^{2}$ sebesar $88,8 \%$. Peneliti selanjutnya diharapkan dapat mengambil variabel lainnya seperti moral reasoning, time budget pressure work family conflict dengan menerapkan di lokasi penelitian yang lain seperti BUMN, pemerintahan dan lainnya.

\section{REFERENSI}

Ade Didik. 2008. Pengaruh Role Stress terhadap Perilaku Disfungsional Internal Auditor. Jurnal Dimensia. 5(1): h: 41-104

Alan T Lord, F Todd Dezoort. 2011. The Impact of Commitment and Moral Reasoning on Auditors Response to Social Influence Pressure. International Journal of Accounting, Organization and Society. 2(6): h: 215-235

Alkautsar, Muslim., 2014. Locus of Control, Commitment Profesional and Dysfunctional Audit Behaviour. International Journal of Humanities and Management Sciences. 2(1): h: 35-38

Balkish Zakaria, Nor., Nurhidayah Yahya, Kalsom Salleh. 2013. Dysfunctional Behavior among Auditors: The Application of Occupational Theory. Journal of Basic and Applied Scientific Research. 3(9): h: 495-503

Bastian, Indra. 2001. Audit Sektor Publik, Jakarta: Visi Global Media. 
Ceacilia Sri Mindarti, Pancawati Hardiningsih, Rachmawati Meita Oktaviani. 2016. Moral Reasoning memoderasi Kompetensi dan Independensi Terhadap Audit. Jurnal Simposium Nasional Akuntansi. 11(1): h:1-25

David N. Herda, Kasey A. Martin. 2016. The Effects of Auditor Experience and Professional Commitment on Acceptance of Underreporting Time: A Moderated Mediation Analysis. International Journal of American Accounting Association. 10(2): h: 14-27

Desmond C.Y. Yuen, Philip K.F. Law, Chan Lu, Jie Qi Guan. 2012. Dysfunctional Auditing Behaviour: Empirical Evidence on Auditors' Behaviour in Macau. International Journal of Accounting and Information Management. 4(5): h: 120

Donnelly, David P., Jeffrey J. Quirin. 2013. Attitudes Toward Dysfunctional Audit Behavior: The Effects Of Locus Of Control, Organizational Commitment, and Position. Journal of Applied Business Research. 19(1): h: 96-108

Faisal. 2007. Tekanan Pengaruh Sosial dalam Menjelaskan Hubungan Moral Reasoning Terhadap Keputusan Auditor. Jurnal Akuntansi dan Keuangan. 4(1): h: $25-46$

Gaffikin, Michael and Lindawati. 2012, The Moral Reasoning of Public Accountants in the Development of a Code of Ethics: the Case of Indonesia. International Journal of Australasian Accounting, Business and Finance. 6(1): h: 3-28

Ghozali, Imam. 2012. Aplikasi Analisis Multivariate dengan Program SPSS. Edisi kc-2. Semarang: Badan Penerbit Universitas Diponegoro.

Gujarati, Damondar. 2008. Ekonometrika Dasar. Jakarta: Erlangga.

Hanifah, Nur., 2017. Pengaruh Time Budget Pressure, Kompensasi dan Moral Reasoning terhadap Dysfunctional Audit Behavior dan Dampaknya terhadap Kualitas Audit. Jurnal Simposium Nasional Akuntansi. 3(2): h:1-34

Ikatan Akuntansi Publik Indonesia. 2009. Kode Etik Profesi Akuntan Publik. Institut Akuntan Publik Indonesia. Jakarta.

lkhsan, Arfan. 2008. Metodologi Penelitian Auditorsi Keperilakuan. Edisi 1. Yogyakarta: Oraha Ilmu. 
ISSN: 2302-8556

E-Jurnal Akuntansi Universitas Udayana

Vol.25.2.November (2018): 1565-1590

Indri Septiani, Ni Made, Sukartha, I Made. 2017. Pengaruh Kompleksitas Audit dan Skeptisme Profesional Auditor pada Penerimaan Perilaku Disfungsional Audit. Jurnal Akuntansi Universitas Udayana. 18(1): h: 471-499

Kreitner dan Kinicki. 2008. Perilaku Organisasi, Jakarta. Selemba Empat

Luc Quadackers, Tom Groot, Arnold Wright. 2008. Auditors' Skeptical Characteristics and Their Relationship to Skeptical Judgments and Decisions. International Journal of Accounting, Organization and Society. 3(1): h: 1-47

Mahatma Setya Devi, Luh,. Suaryana I G.N.A,. 2016. Time Budget Pressure Memoderasi Pengaruh Karakteristik Personal Auditor terhadap Penerimaan Perilaku Disfungsional Audit. Jurnal Akuntansi Universitas Udayana. 15(3): h: 1994-2023

Mangkunegara, A. A. Anwar Prabu. 2011. Manajemen Sumber Daya Manusia Perusahaan. Bandung: PT. Remaja Rosdakarya

Mark W. Nelson. 2009. A Model and Literature Review of Professional Skepticism in Auditing. International Journal of American Accounting Association. 28(2): h: $1-34$

Medhat Endrawes, Gary S. Monroe. 2015. Professional Scepticism of Auditors: A Cross-Cultural Experiment. International Journal of American Accounting Association. 51(2): h: 1-41

Mulyadi, 2011. Auditing. Edisi ke-6. Jakarta: Salemba Empat.

Ongky Hartanto. 2012. Pengaruh Locus of Control, Tekanan Anggaran Waktu, Komitmen Profesional, Terhadap Perilaku Disfungsional Auditor. Jurnal Ekonomi dan Keuangan. 20(4): h: 473 - 490

Paneeda Tangsakul, Phaprukbaramee Ussahawanitchakit. 2015. Moral Reasoning of Tax Auditors in Thailand: An Empirical Investigation of the Antecedents and Consequences. International Journal of The Business and Management Review. 7(1): h: 134-142

Peyman Tabatabaei Fakhar, Ali Hoseinzadeh. 2016. Investigate The Effect of Organizational Commitment and Professional Commitment on Dysfunctional Behavior of Auditors. International Academic Journal of Accounting and Financial Management. 3(1): h: 1-12 
Riduwan dan Sunarto. 2007. Pengantar Statistika Untuk Penelitian Pendidikan, Sosial, Ekonomi, dan Bisnis. Bandung : Alfabeta.

Rieke Sri Rizki Asti Karini. 2015. Stress Role and Dysfunctional Behavior on The Performance of Internal Auditor. Journal of Trikonomika. 14(2): h: 129-137

Robbins, Stephen P. 2008. "Perilaku Organisasi". (judul asli: Organizational Behavior Concept, Controversies, Applications 12th edition) Jilid 1.Penerjemah Diana Angelica

Robbins, S.P., and Judge, T.A. 2011. Perilaku Organisasi, Edisi Kedua belas,Jakarta: Salemba Empat

Rustiarini, Ni Wayan., 2014. Sifat Kepribadian sebagai Pemoderasi Hubungan Stres Kerja dan Perilaku Disfungsional Audit. Jurnal Akuntansi dan Keuangan Indonesia. 11(1): h: 1-19

Sartika. 2013. Pengaruh Sifat Mchiavellian dan Perkembangan Moral terhadap Perilaku Disfungsional. (Studi Empiris pada Perusahaan Manufaktur Kota Padang). Jurnal Simposium Nasional Akuntansi. 4(2): h:1-32

Sawyer, 2008. Internal Auditing The Practice of Modern Internal Auditing, 4th edition, Altamonte Springs, California: The Institute of Internal Auditor

Siti Kustinah. 2013. The Influence of Dysfunctional Behavior And Individual Culture On Audit Quality. International Academic Journal of Scientific \& Technology Research. 2(5): h: 118-125

Sudarshan K. Pillalamarri. 2015. The Role of Moral Reasoning and Order Effects on Ethical Decision-Making Ability: Novice vs. Experienced Accounting Students. International Journal of American Accounting Association. 4(2): h: $1-22$

Sugiyono. 2013. Metode Penelitian Bisnis. Bandung: CV. Alfabeta.

Suyana Utama, Made. 2009.“Buku Ajar Aplikasi Analisis Kuantitatif. Denpasar: Fakultas Ekonomi Universitas Udayana

Syarhayuti, Faidul Adziem. 2016. Pengaruh Moral Reasoning, Skeptisme Profesional dan Kecerdasan Spiritual terhadap Kualitas Audit dengan Pengalaman Kerja Auditor sebagai variabel moderating di Inspektorat Provinsi Sulawesi Selatan. Jurnal Akuntansi Peradaban. 1(1): h: 128-148 